\title{
Synthesis of pH-degradable polyglycerol-based nanogels by iEDDA-mediated crosslinking for encapsulation of asparaginase using inverse nanoprecipitation
}

\author{
Alexander Oehrl ${ }^{1} \cdot$ Sebastian Schötz $^{1} \cdot$ Rainer Haag $^{1}$ (D) \\ Received: 20 November 2019 / Revised: 14 May 2020 / Accepted: 14 May 2020 / Published online: 6 June 2020 \\ (C) The Author(s) 2020
}

\begin{abstract}
Biocompatible, environmentally responsive, and scalable nanocarriers are needed for targeted and triggered delivery of therapeutic proteins. Suitable polymers, preparation methods, and crosslinking chemistries must be considered for nanogel formation. Biocompatible dendritic polyglycerol ( $\mathrm{dPG}$ ) is used in the mild, surfactant-free inverse nanoprecipitation method for nanogel preparation. The biocompatible, fast, and bioorthogonal inverse electron demand Diels-Alder (iEDDA) crosslinking chemistry is used. In this work, the synthesis of $\mathrm{pH}$-degradable nanogels, based on tetrazine, norbonene, and bicyclo[6.1.0]nonyne (BCN) functionalized macromonomers, is reported. The macromonomers are non-toxic up to $2.5 \mathrm{mg} \mathrm{mL} \mathrm{m}^{-1}$ in three different cell lines. Nanogels are obtained in the size range of 47 to $200 \mathrm{~nm}$ and can be degraded within $48 \mathrm{~h}$ at pH 4.5 (BA-gels), and pH 3 (THP-gels), respectively. Encapsulation of asparaginase $(32 \mathrm{kDa}$ ) yield encapsulation efficiencies of up to $93 \%$ at $5 \mathrm{wt} . \%$ feed. Overall, iEDDAcrosslinked pH-degradable dPG-nanogels from inverse nanoprecipitation are promising candidates for biomedical applications.
\end{abstract}

Keywords iEDDA $\cdot$ Nanogels $\cdot$ Inverse nanoprecipitation $\cdot \mathrm{pH}$ degradability $\cdot$ Protein encapsulation

\section{Introduction}

Modern medicine has a high demand for new and smart nanocarrier systems for drug delivery, that improve pharmacokinetics, permit the use of less overall drug, thus reduce side effects, and lead to prolonged drug circulation time, and can deliver their cargo specifically to diseased tissue and not to healthy tissue [1]. Additionally, these carrier systems must be biocompatible and either biodegradable or be easily excreted by the body after delivering their cargo [2, 3]. Any degradation products and metabolites must be non-toxic. Attempts have been made to design such nanocarriers for a variety of drugs. In the class of hydrophobic drugs, there are already some examples on the market, such as liposomal formulations of the anticancer drugs doxorubicin (Doxil®) and

Electronic supplementary material The online version of this article (https://doi.org/10.1007/s00396-020-04675-8) contains supplementary material, which is available to authorized users.

Rainer Haag

haag@chemie.fu-berlin.de

1 Institute for Chemistry and Biochemistry, Freie Universität Berlin, Takustr. 3, D-14195 Berlin, Germany daunorubicin (DaunoXome ${ }^{\circledR}$ ), and micellar estradiol (Estrasorb ${ }^{\mathrm{TM}}$ ) [4]. However, liposomal formulations cannot be considered smart or responsive carriers, as they lack the structural properties to respond to external stimuli. For the more sensitive drugs, such as therapeutic proteins, liposomal formulations are not very suitable. The detergent nature of the liposomes can disrupt the natural folding of the proteins and thus lead to a loss of function. However, especially this type of drug needs improved delivery systems. Proteins are usually injected intravenously to the body, due to low stability in the strongly acidic environment of the stomach or due to very low absorption within the small intestine [5]. In the blood stream, the mononuclear phage system (MPS), a part of the immune system, effectively removes foreign substances from the body. Proteins are easily recognized by the MPS and are thus eliminated quite fast $[4,6,7]$. Apart from the MPS, small proteins are also excreted via the kidney if their molecular weight is below the renal threshold of $45 \mathrm{kDa}$ or hydrodynamic diameter of $5.5 \mathrm{~nm}[8-10]$. This shows that nanocarriers are needed for protein delivery, which are able to increase the total molecular weight of the therapeutics to prolong circulation times and offer evasion from the MPS clearance. Currently, the only type of carriers that fulfill these criteria and are on the market, are polyethylene glycol (PEG) protein conjugates. PEG is a 
hydrophilic and size-tunable, biocompatible polymer that is attached randomly, or site specific to the protein. This increases the total molecular weight above the renal threshold and leads to increased circulation times and reduced clearance through the MPS [11-13]. However, recently PEG has shown to be able to induce immune responses in some patients, leading to reduced effectivity of the treatment $[14,15]$. Furthermore, targeted delivery is not possible with PEG conjugation and can also reduce the activity of the protein that it is conjugated to. Thus, alternatives that provide the same advantages as PEG, but additionally also allow for a targeted delivery and release of the protein are needed.

Alternatively nanogels consist of hydrophilic polymer networks in the size range of 10 to $1000 \mathrm{~nm}$ and offer a hydrophilic environment that shields any cargo encapsulated inside [16-21]. The properties of these gels can be tuned, based on the polymers that are used for the network formation. A variety of options exist and have been intensively studied. Natural polymers such as alginate [22], dextran [23], and chitosan [24] have been used for nanogel preparation. However, synthetically easily accessible polymers such as PEG [25], copolymers of polylactic and glycolic acid (PLA/PLA-co-PGA) [26], linear polyglycerol (IPG) [27], and dendritic polyglycerol (dPG) [27-30] have also been successfully used for nanogel formation. The introduction of environmentally responsive groups, such as $\mathrm{pH}$-sensitive acetals [31-33], or redox-sensitive disulfides $[16,34]$ can then be used for the preparation of degradable nanogels. For example, within endosomes and lysosomes, the $\mathrm{pH}$ value drops to values between 4 and 6 [35].

Beside network material, the preparation method also has a big influence on the suitability of the carrier for biomedical applications. Nanogels have been prepared by methods such as micro- and miniemulsion polymerization [23, 36-38]. However, the use of surfactants, heat, and ultrasound can be detrimental for the encapsulation of sensitive biotherapeutics. Furthermore, surfactants are sometimes hard to remove and can have a negative impact on cell viability and applicability in vitro and in vivo.

Technologies such as the nanoprecipitation method, where nanoparticles are formed by precipitation in their corresponding non-solvent water, have been adjusted to hydrophilic macromonomers [39-41]. This inverse nanoprecipitation leads to hydrophilic nanogels by precipitation of the macromonomers in solvents like acetone. Thus, very mild conditions for the encapsulation of proteins are present, as no surfactants or ultrasound are used $[28,30]$.

For the inverse nanoprecipitation method, usually macromonomers are used that crosslink in situ during the precipitation process. In order to have a reasonably fast gelation, the type of crosslinking chemistry plays a major role for successful preparation of nanogels. Suitable chemistries include the click-type copper-catalyzed azide alkyne cycloaddition (CuAAC) [30], the strain-promoted version of $\mathrm{CuAAC}$
(SPAAC) [27], thiol-Michael addition [42], and inverse electron demand Diels-Alder (iEDDA). CuAAC is suitable for gel formation; however, the toxic copper ions are hard to remove and can have toxicity in vivo. thiol-Michael addition is fast and scalable, however, not suitable for proteins containing thiols, as a cross-reactivity exists. SPAAC offers a fast gelation, as well as very low cross-reactivity with free thiols. However, the synthetic precursors are expensive and exhibit low-yielding, long synthetic procedures. In contrast, iEDDA reactions between tetrazine derivatives and dienophiles are so fast and bioorthogonal [43-46] that they have been used for fluorescent labeling of antibodies [47], DNA-tagging [48], and even cell labeling [49]. The synthetic precursors are inexpensive and prepared in a straightforward manner. Depending on the application, one can choose between different reactivities and thus gelation times. As there are no side reactions with biological systems, this method is one of the most bioorthogonal reactions available so far. Furthermore, no toxic catalysts, such as copper ions, are needed, which makes iEDDA a very promising coupling strategy for the preparation of biocompatible nanogels.

We present the synthesis of new pH-cleavable macromonomers based on the biocompatible and easy to functionalize dPG [12, 50-52] with methyl-tetrazine and the dienophiles norbonene and bicyclo[6.1.0]non-4-yne $(\mathrm{BCN})$ as iEDDA reactive functional groups. $\mathrm{pH}$ degradability is introduced by incorporation of benzacetal (BA) and tetrahydropyran (THP)-based acetals into the macromonomers which cleave at $\mathrm{pH}$ values of 5 and 3, respectively. The macromonomers are characterized by NMR, IR, and DLS and tested regarding their ability to form stable nanogels during inverse nanoprecipitation in acetone under various reaction conditions. dPG-BA-norbonene and dPG-THP-norbonene are used for encapsulation of the therapeutic protein asparaginase with excellent encapsulation efficiencies of up to $93 \%$. The BA-based gels are cleaved completely within $48 \mathrm{~h}$ at $\mathrm{pH} 4.5$, while the THP-based gels were degraded at pH 3 within $48 \mathrm{~h}$. The macromonomers were tested in a cell viability assay with three different cell lines and did not show toxicity up to about $2.5 \mathrm{mg} \mathrm{mL}^{-1}$.

The fast and efficient synthetic route to $\mathrm{pH}$-cleavable macromonomers with iEDDA reactive groups, as well as the stable and scalable nanogels that are obtained from them, while avoiding the drawbacks of toxic catalysts or side reactivity in other crosslinking strategies, makes this a nanocarrier system with potential biomedical application.

\section{Materials and methods}

\section{Materials}

Ethyl acetate, $n$-pentane, and diethyl ether were obtained from the technically pure solvents by distillation before use. Dry DCM and THF were used from a SPS-800-type MBRAUN 
solvent drying system. Acetone and DCM (HPLC grade) were used without further purification. Dry methanol and DMF were purchased from Acros and Fischer Chemical. All other chemicals and deuterated solvents were obtained from SigmaAldrich, Acros, Merck, and Fisher Chemicals and were used as without further purification. Thin layer chromatography (TLC) was performed on silica gel-coated aluminum plates, serving as stationary phase (silica gel 60 F254 from Macherey-Nagel). Identification of analytes was done by UV-irradiation ( $\lambda=254 \mathrm{~nm}$ ) of the TLC plates or by treatment with a potassium permanganate-based $(100 \mathrm{~mL}$ deionized water, $200 \mathrm{mg}$ potassium permanganate) or anis aldehydebased staining solution $(450 \mathrm{~mL}$ EtOH, $25 \mathrm{~mL}$ anis aldehyde, $25 \mathrm{~mL}$ conc. sulfuric acid, $8.0 \mathrm{~mL}$ acetic acid). Column chromatography was performed with silica gel (Macherey-Nagel, grain size $40-63 \mu \mathrm{m}, 230-400$ mesh) as stationary phase and the indicated eluent mixtures as the mobile phase.

\section{Analytical methods}

IR spectra were recorded on a JASCO FT/IR-4100 spectrometer. The characteristic absorption bands are given in wave numbers. ${ }^{1} \mathrm{H}$ NMR spectra were recorded at $300 \mathrm{~K}$ on Joel ECX $400400 \mathrm{MHz}$ and AVANCE III (700 MHz) instruments. Chemical shifts $\delta$ are indicated in parts per million (ppm) relative to tetramethyl silane $(0 \mathrm{ppm})$ and calibrated as an internal standard to the signal of the incompletely deuterated solvent ( $\left.\mathrm{CDCl}_{3}: \delta=7.26 \mathrm{ppm}, \mathrm{MeOD}: \delta=3.31 \mathrm{ppm}\right)$. Coupling constants $J$ are given in Hertz (Hz). ${ }^{13} \mathrm{C}$ NMR spectra were recorded at $300 \mathrm{~K}$ on AVANCE III instruments (176 $\mathrm{MHz})$. Chemical shifts $\delta$ are given in ppm relative to tetramethyl silane $(0 \mathrm{ppm})$ and calibrated as an internal standard to the signal of the incompletely deuterated solvent $\left(\mathrm{CDCl}_{3}: \delta=77.16 \mathrm{ppm}, \mathrm{MeOD}: \delta=49 \mathrm{ppm}\right)$. Coupling constants $J$ are given in Hertz $(\mathrm{Hz})$. The spectra are decoupled from proton broadband. DLS and Zeta potential were measured on a Malvern zeta-sizer nano ZS 90 with $\mathrm{He}-\mathrm{Ne}$ laser $(\lambda$ $=532 \mathrm{~nm}$ ) at $173^{\circ}$ backscatter and automated attenuation at 25 ${ }^{\circ} \mathrm{C}$. Three measurements were performed per sample, yielding a mean size value plus an error estimate. Sample concentration was kept at $1 \mathrm{mg} \mathrm{mL}{ }^{-1}$. GPC was performed on an Agilent 1100 at $5 \mathrm{mg} \mathrm{mL}^{-1}$ using a pullulan standard, 0.1 M NaNO3 solution as eluent and a PSS Suprema column $10 \mu \mathrm{m}$ with a flow rate of $1 \mathrm{~mL} \mathrm{~min}{ }^{-1}$. Signals were detected with an RI detector.

\section{Precursors and macromonomers}

All air- and moisture-sensitive reactions were carried out in flasks in an inert atmosphere (argon) using conventional Schlenk techniques. Reagents and solvents were added via argon-rinsed syringes. Solids were added in argon counterflow as solutions in the corresponding solvent.
The synthesis of the literature known precursors is described in the Supporting Information, showing the modified procedures.

\section{2-(Azidomethyl)-3,4-dihydro-2H-pyran (5)}

(3,4-Dihydro-2H-pyran-2-yl)methanol (1.58 g, $13.84 \mathrm{mmol})$ and $\mathrm{Et}_{3} \mathrm{~N}(2.10 \mathrm{~g}, 20,76 \mathrm{mmol}, 2.88 \mathrm{~mL})$ were dissolved in DCM $(25 \mathrm{~mL})$. Methane sulfonyl chloride $(1.74 \mathrm{~g}, 15.23$ mmol, $1.18 \mathrm{~mL}$ ) was added dropwise via syringe. The solution was stirred for $45 \mathrm{~min}$ at $0{ }^{\circ} \mathrm{C}$. Saturated aqueous $\mathrm{NaHCO}_{3}$ solution was added, phases were separated, and the aqueous phase was extracted with DCM $(3 \times 25 \mathrm{~mL})$. The combined organic layers were dried with $\mathrm{Na}_{2} \mathrm{SO}_{4}$. The solvent was removed under reduced pressure.

The crude product (2.84 g, $14.77 \mathrm{mmol})$ was dissolved in DMF $(20 \mathrm{~mL})$, and $\mathrm{NaN}_{3}(9.60 \mathrm{~g}, 147.67 \mathrm{mmol})$ was added. The solution was stirred at $55^{\circ} \mathrm{C}$ for 3 days. Water $(20 \mathrm{~mL})$ was added, the phases were separated, and the aqueous phase was extracted with DCM $(3 \times 25 \mathrm{~mL})$. The combined organic layers were dried with $\mathrm{Na}_{2} \mathrm{SO}_{4}$. The solvent was removed under reduced pressure. The crude product was purified by column chromatography (pentan/EtOAc, 10:1) to give the product (30) $(1.91 \mathrm{~g}, 13.76 \mathrm{mmol}, 93 \%$ over 2 steps $)$ as a colorless oil.

${ }^{1} \mathrm{H}-\mathrm{NMR}\left(400 \mathrm{MHz}, \mathrm{CD}_{3} \mathrm{OD}\right) \delta=6.38(\mathrm{~d}, J=6.2 \mathrm{~Hz}, 1 \mathrm{H}, \mathrm{H}-$ olefin-O), 4.74-4.72 (m, 1 H, H-olefin), 4.01-3.96 (m, $1 \mathrm{H}$, H-tertiary), 3.48-3.32 (m, $2 \mathrm{H}, \mathrm{H}-\mathrm{CN} 3), 2.16-1.58$ (m, $4 \mathrm{H}$, H-ring) ppm.

\section{dPG-THP-azide ${ }_{5}$}

dPG $(0.12 \mathrm{~g}, 1.44 \mathrm{mmol})$ was dried under $\mathrm{HV}$ at $70{ }^{\circ} \mathrm{C}$ overnight and dissolved in dry DMF (10 mL). The DHP-azide (5) $(0.02 \mathrm{~g}, 0.15 \mathrm{mmol})$ was dissolved in dry DMF $(5 \mathrm{~mL})$ and added to the dPG-solution via syringe, and $p$-TSA $(1.90 \mu \mathrm{g}$, $0.01 \mathrm{mmol}$ ) was added. The resulting solution was stirred at room temperature overnight. After quenching with a small excess of $\mathrm{NEt}_{3}$, the crude product was constricted under reduced pressure and dialyzed against $\mathrm{H}_{2} \mathrm{O}$ and methanol 1:1 for 4 days and methanol for 3 days ( $\mathrm{MWCO}=1 \mathrm{kDa}$ ). The product was obtained as methanolic solution $(5.0 \%$ functionalization, $85 \%$ ).

${ }^{1} \mathrm{H}-\mathrm{NMR}\left(700 \mathrm{MHz}, \mathrm{CD}_{3} \mathrm{OD}\right) \delta=4.59-4.53(\mathrm{~m}, 1 \mathrm{H}, \mathrm{H}-$ $\left.\mathrm{C}_{2} \mathrm{H}_{2} \mathrm{~N}_{3}\right), 4.21-14\left(\mathrm{~m}, 1 \mathrm{H}, \mathrm{H}-\mathrm{C}_{2} \mathrm{H}_{2}\right.$-carbamate), 4.04 (dPG-backbone), 3.33-3.20 (m, $2 \mathrm{H}, \mathrm{H}-\mathrm{C}$-carbamate), 1.99-1.39 (m, $6 \mathrm{H}, \mathrm{H}$-ring) ppm.

${ }^{13} \mathrm{C}-\mathrm{NMR}\left(176 \mathrm{MHz}, \mathrm{CD}_{3} \mathrm{OD}\right) \delta=101.4,80.0,79.9,79.5,79.3$, 79.1, 74.1, 74.0, 72.6, 72.5, 72.2, 70.7, 70.67, 64.5, 64.4, 33.1, $29.1 \mathrm{ppm}$. 
IR (ATR) $\tilde{\nu}=3375,2919,2871,2357,2332,2099,1649,1450$, $1324,1300,1261,1067 \mathrm{~cm}^{-1}$.

EA $\left(\mathrm{C}_{66} \mathrm{H}_{31} \mathrm{~N}_{3} \mathrm{O}_{42}\right)$ calc. C (48.37\%), found C $(49.46 \%)$; calc. $\mathrm{N}$ ( $2.56 \%$ ), found $\mathrm{N}(2.62 \%)$, calc. $\mathrm{H}(8.06 \%)$, found $\mathrm{H}(8.47 \%)$.

\section{dPG-THP-amine ${ }_{5} \%$}

The dPG-THP-azide (1.67 g, $22.21 \mathrm{mmol}, 1.13 \mathrm{mmol}$ azide) was dissolved in THF $(70 \mathrm{~mL})$. Distilled water $(80 \mathrm{~mL})$ and $\mathrm{PPh}_{3}(3.50 \mathrm{~g}, 13.33 \mathrm{mmol})$ were added, and the solution was stirred for 7 days at room temperature. THF was removed under reduced pressure and the crude product was filtered. The filtrate was constricted under reduced pressure. The crude product was dialyzed against methanol for 5 days $(\mathrm{MWCO}=$ $1 \mathrm{kDa}$ ). The product was obtained as a methanolic solution (5.0\% functionalization, $95 \%$ ).

${ }^{1} \mathrm{H}-\mathrm{NMR}$ (700 MHz, CD $\left.\mathrm{OD}\right) \delta=4.76-4.65$ (m, $2 \mathrm{H}, \mathrm{H}$-acetal), 4.24-4.03 (m, 2 H, H-C2H6N), 4.00-3.43 (dPG-backbone), 2.96-2.68 (m, 2 H, H-tertiary), 2.02-1.17 (m, 6 H, H-ring) ppm.

${ }^{13}$ C-NMR (176 MHz, CD ${ }_{3}$ OD) $\delta=170.3,142.7,103.3,81.7$, 81.4, 80.2, 79.9, 73.98, 74.0, 73.0, 72.4, 72.2, 71.0, 70.7, $70.7,64.5,64.4,62.8,49.4 \mathrm{ppm}$.

IR (ATR) $\tilde{\nu}=3359,2913,1871,2380,1650,1456,1327,1067$, $1030,931,866.748 \mathrm{~cm}^{-1}$.

\section{General procedure for dPG-dienophiles}

All dPG-dienophiles were synthesized according to the same general procedure. As an example, dPG-BA-norbonene is described in detail.

\section{dPG-BA-norbonene ${ }_{8 \%}$ (MM4)}

Dry DMF $(7.50 \mathrm{~mL})$ was added to a methanolic solution of dPG-benzacetal-amine $(10.00 \mathrm{~mL}, 0.062 \mathrm{~g} / \mathrm{mL})$. Methanol was removed under reduced pressure. Fresh dry DMF (7.50 $\mathrm{mL}$ ) was added, the solution was constricted under reduced pressure to $15 \mathrm{~mL}$, and $\mathrm{Et} 3 \mathrm{~N}(0.18 \mathrm{~g}, 1,83 \mathrm{mmol}, 0.25 \mathrm{~mL})$ was added. Norbonene active carbonate (2) $(0.19 \mathrm{~g}, 0.67$ $\mathrm{mmol})$ was dissolved in DMF $(10 \mathrm{~mL})$, and the solution was added dropwise via syringe to the $\mathrm{dPG}$-amine solution. The resulting reaction mixture was stirred at room temperature overnight. The crude product was dialyzed against a mixture of water and acetone (1:1) and methanol for 4 days (MWCO = $1 \mathrm{kDa}$ ). The product was obtained as a yellow methanolic solution $(88 \%, 7.5 \%$ functionalization).
${ }^{1} \mathrm{H}-\mathrm{NMR}\left(700 \mathrm{MHz}, \mathrm{CD}_{3} \mathrm{OD}\right) \delta=7.49-7.35(\mathrm{~m}, 2 \mathrm{H}, \mathrm{H}$-aromatic), 7.02-6.88 (m, $2 \mathrm{H}, \mathrm{H}$-aromatic), $6.20-6.06(\mathrm{~m}, 1 \mathrm{H}, \mathrm{H}-$ olefin), 5.99-5.84 (m, $1 \mathrm{H}, \mathrm{H}-$ olefin), 5.78-5.68 (m, $1 \mathrm{H}, \mathrm{H}-$ acetal), $4.63-4.54$ (m, 2 H, H-C-carbamate), $4.47-4.22$ (m, 2 $\mathrm{H}, \mathrm{H}-\mathrm{C}-\mathrm{OPh}$ ), 4.11-3.44 (dPG-backbone), 3.32-3.28 (m, 2 $\mathrm{H}, \mathrm{H}-\mathrm{C}-\mathrm{NH}), 2.91-2.85$ (m, $1 \mathrm{H}, \mathrm{H}-$ ring), $2.85-2.80$ (m, $1 \mathrm{H}$, H-ring), 2.03-1.94 (m, $2 \mathrm{H}, \mathrm{H}-$-ring), $1.90-1.82(\mathrm{~m}, 1 \mathrm{H}, \mathrm{H}-$ ring), $1.42-1.14$ (m, $2 \mathrm{H}, \mathrm{H}$-aliphatic) ppm.

${ }^{13} \mathrm{C}-\mathrm{NMR}\left(176 \mathrm{MHz}, \mathrm{CD}_{3} \mathrm{OD}\right) \delta=161.4,161.2,159.2,138.6$, 138.0, 137.4, 133.3, 129.6, 129.3, 115.4, 105.6, 104.9, 81.4, $80.2,79.9,76.6,74.1,74.0,73.0,73.0,72.6,72.5,72.4,72.2$, 71.0, 70.8, 69.2, 68.6, 66.7, 64.5, 64.4, 62.8, 50.4, 45.9, 45.1, $43.5,42.8,39.5,38.9,30.8,30.4,29.9$ ppm. 48

IR (ATR) $\tilde{\nu}=3374,2871,1696,1614,1517,1458,1394,1327$, 1304, 1244, 1075, $977 \mathrm{~cm}^{-1}$.

EA $\left(\mathrm{C}_{847} \mathrm{H}_{1475} \mathrm{~N}_{13} \mathrm{O}_{440}\right)$ calc. C (53.88\%), found C (53.29\%); calc. N $(0.96 \%)$, found $\mathrm{N}(1.94 \%)$; calc. H $(7.87 \%)$, found $(8.21 \%)$

\section{dPG-THP-norbonene 5\% (MM6)}

DMF (10 mL), dPG-THP-NH 2 (440 mg, $0.3 \mathrm{mmol} \mathrm{NH}_{2}$ ), $\mathrm{NEt}_{3}(170 \mu \mathrm{L}, 3 \mathrm{eq}), \mathrm{BCN}$ (132 mg, $0.42 \mathrm{mmol}$ ) in DMF (3 $\mathrm{mL}$ ). The product was stored as the methanolic solution in the freezer $(5 \%, 91 \%)$.

${ }^{1} \mathrm{H}-\mathrm{NMR}$ (700 MHz, CD $\left.30 \mathrm{O}\right) \delta=6.23-6.02$ (m, $2 \mathrm{H}, \mathrm{H}$-olefin), 3.95-3.54 (m, dPG-backbone, 2.94-0.61 (m, 6 H, aliphaticH).

${ }^{13} \mathrm{C}-\mathrm{NMR}\left(176 \mathrm{MHz}, \mathrm{CD}_{3} \mathrm{OD}\right) \delta=159.23,138.54,133.31$, 98.72, 81.64, 81.43, 80.16, 79.89, 73.99, 72.96, 72.46, $72.23,70.98,70.68,69.33,64.42,62.83,50.37,49.85$, $45.12,43.49,42.86,39.79,39.50,30.62,29.88,29.06$, $24.55,18.79$.

\section{dPG-THP-BCN $5 \%$ (MM7)}

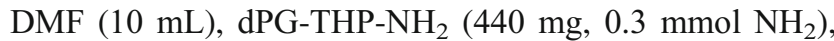
$\mathrm{NEt}_{3}(170 \mu \mathrm{L}, 3 \mathrm{eq}), \mathrm{BCN}$ (144 mg, $0.45 \mathrm{mmol}$ ) in DMF (3 $\mathrm{mL}$ ). The product was stored as the methanolic solution in the freezer ( $5 \%$, quantitative).

${ }^{1} \mathrm{H}-\mathrm{NMR}\left(700 \mathrm{MHz}, \mathrm{CD}_{3} \mathrm{OD}\right) \delta=3.96-3.55$ (m, dPG-backbone), $2.44-0.73(\mathrm{~m}, 11 \mathrm{H}$, aliphatic-H-BCN).

${ }^{13} \mathrm{C}-\mathrm{NMR}\left(176 \mathrm{MHz}, \mathrm{CD}_{3} \mathrm{OD}\right) \delta=157.96,98.28,80.25,80.04$, 78.82, 78.51, 72.62, 71.58, 71.07, 70.84, 69.61, 69.30, 67.87, $63.11,63.03,61.43,48.46,33.07,28.85,28.04,23.72,22.84$, $20.63,20.05,17.62,17.40$. 


\section{Inverse nanoprecipitation of macromonomers}

General procedure The ratio of macromonomer A (dPGmetTet) to macromonomer B (dPG-dienophile) was set to $1: 1.5$. Acetone was used as the non-solvent. Parameters, such as solvent to non-solvent ratio $(1: 20-1: 80)$ and water quenching time $T_{\mathrm{q} \text {, water }}(0-120 \mathrm{~min})$, were varied according to the tables described in the "Results and discussion" section. As an example, a general procedure for one set of parameters is described in detail below.

Macromonomers A and B were stored as stock-solutions of 100 to $150 \mathrm{mg} \mathrm{mL}^{-1}$ in water. Aliquots were taken and separately diluted with water to a final volume of $1 \mathrm{~mL}$. For this, $15 \mu \mathrm{L}$ of macromonomer $\mathrm{A}$ was diluted with $485 \mu \mathrm{L}$ water and $22.5 \mu \mathrm{L}$ of macromonomer B with $477.5 \mu \mathrm{L}$ water. Both solutions were cooled in an ice bath to $4{ }^{\circ} \mathrm{C}$. Macromonomer A solution was added fast to solution B and vortexed for $5 \mathrm{~s}$. Then, the solution was added fast via syringe to a $60-\mathrm{mL}$ glass vial containing magnetically stirred acetone $(40 \mathrm{~mL})$ at 1200 $\mathrm{rpm}$. The turbid dispersion was stirred for another $2 \mathrm{~s}$ and then kept still for $10 \mathrm{~min}$. The reaction was then quenched by the addition of $20 \mu \mathrm{L}$ of 2-(vinyloxy)ethan-1-ol. Water (1/3 of acetone) was added after $30 \mathrm{~min}$, and the acetone was removed under reduced pressure. Purification was performed by centrifugal filtration, using a membrane with a cutoff of 1 MDa and 3 consecutive washing steps with $10 \mathrm{~mL}$ distilled water/PBS buffer each. Nanogels were obtained as stable dispersions in water and characterized using DLS, NTA, and Zeta-potential measurements.

\section{Co-precipitation of asparaginase}

The inverse nanoprecipitation was performed as described in "Inverse nanoprecipitation of macromonomers." Two hundred twenty-five microliters of a $1.11 \mathrm{mg} / \mathrm{mL}$ stock solution of asparaginase was added to the dPG-metTet macromonomer solution and thoroughly mixed. The total volume of water was kept at $1 \mathrm{~mL} .5 \mathrm{wt} \%$ of asparaginase was encapsulated each for dPG-norbonene-, dPG-BA-norbonene, and dPG-THPnorbonene-NGs $(n=3)$. The gels were purified by centrifugation filtration, using filters with a molecular weight cut-off of 1 $\mathrm{MDa}$ at $234 \mathrm{rcf}$. The gel volume was reduced to $1 \mathrm{~mL}$ and fresh PBS buffer was added $(10 \mathrm{~mL})$. Then, the volume was reduced to $1 \mathrm{~mL}$ again and the whole process was repeated three times to ensure the complete removal of the nonencapsulated protein.

\section{Protein content determination assay}

A standard Pierce BCA assay kit was used for the determination of asparaginase content within the nanogels. Twenty-five microliters of the purified nanogels was added to a 96-well plate. Then, $200 \mu \mathrm{L}$ of working reagent was added to each well and the plate was shaken for $30 \mathrm{~s}$ on a plate shaker. The plate was then incubated at $37^{\circ} \mathrm{C}$ for $1 \mathrm{~h}$. After cooling to room temperature, the absorbance was measured at $562 \mathrm{~nm}$ on a plate reader. Samples were recorded in triplicate and for three independent gels of the same type. Calibration curves were prepared for a dilution series of albumin and asparaginase in the range of 0 to $1000 \mu \mathrm{g} \mathrm{mL} \mathrm{m}^{-1}$. Concentrations of asparaginase in the samples were determined via the fitted standard curves of asparaginase (Figure S4).

\section{Degradation of nanogels}

For the continuous degradation experiments, $100 \mu \mathrm{L}$ of $2 \mathrm{mg} /$ $\mathrm{mL}$ was diluted with buffer to $200 \mu \mathrm{L}$ total volume. For each $\mathrm{pH}$ value, a different buffer was used. In the case of $\mathrm{pH} 7.4$, a $10 \mathrm{mM}$ PBS buffer; in the case of $\mathrm{pH} 4.5,10 \mathrm{mM}$ acetate buffer; and in the case of $\mathrm{pH} 3$, the same acetate buffer with addition of $1 \mathrm{M} \mathrm{HCl}$ were used.

The solutions were placed in a disposable UV-cuvette and measured continuously with a Malvern zeta-sizer nano ZS 90 with $\mathrm{He}-\mathrm{Ne}$ laser $(\lambda=532 \mathrm{~nm})$ at $173^{\circ}$ backscatter and automated attenuation at $25^{\circ} \mathrm{C}$ for $16 \mathrm{~h}$.

For nanogels with protein content $333 \mu \mathrm{L}$ of $1.1 \mathrm{mg} / \mathrm{mL}$ nanogel dispersion were diluted with $500 \mu \mathrm{L}$ of the buffer solutions and agitated continuously with a vortex at lowest agitation speed for $48 \mathrm{~h}$. At $30 \mathrm{~min}, 1 \mathrm{~h}, 3 \mathrm{~h}, 5 \mathrm{~h}, 8 \mathrm{~h}, 24 \mathrm{~h}$, and $48 \mathrm{~h}$, a sample of $70 \mu \mathrm{L}$ was taken for each $\mathrm{pH}$ value, snap frozen in liquid nitrogen, and stored at $-20^{\circ} \mathrm{C}$ in the freezer. Particle size distributions were measured for each time point and $\mathrm{pH}$ value using a Malvern zeta-sizer nano ZS 90 with $\mathrm{He}-$ Ne laser $(\lambda=532 \mathrm{~nm})$ at $173^{\circ}$ backscatter and automated attenuation at $25^{\circ} \mathrm{C}$. A mean of three measurements is reported.

\section{Cell viability assay}

Cell viability was determined using a CCK-8 Kit (SigmaAldrich) according to the manufacturer's instructions. A549, HeLa, and MCF-7 cells were obtained from Leibniz-Institut DSMZ - Deutsche Sammlung von Mikroorganismen und Zellkulturen GmbH and cultured in DMEM (A549 cells) or RPMI 1640 (HeLa and MCF-7 cells) supplemented with 10\% $(\mathrm{v} / \mathrm{v}) \mathrm{FBS}, 100 \mathrm{U} / \mathrm{mL}$ penicillin, and $100 \mu \mathrm{g} \mathrm{\textrm {mL } ^ { - 1 }}$ streptomycin.

A549, HeLa, and MCF-7 cells were seeded in a 96-well plate at a density of $5 \times 10^{4}$ cells $/ \mathrm{mL}$ in $90 \mu \mathrm{L}$ DMEM/RPMI Medium per well over night at $37{ }^{\circ} \mathrm{C}$ and $5 \% \mathrm{CO}_{2}$. Ten microliters of dPG-metTet or dPG-dienophile (solved in deionized water) was added in serial dilutions including positive ( $1 \%$ and $0.1 \%$ SDS) and negative controls (cell culture medium and $10 \% \mathrm{H}_{2} \mathrm{O}$ in cell culture medium) and incubated for another $24 \mathrm{~h}$ at $37{ }^{\circ} \mathrm{C}$ and $5 \% \mathrm{CO}_{2}$. 


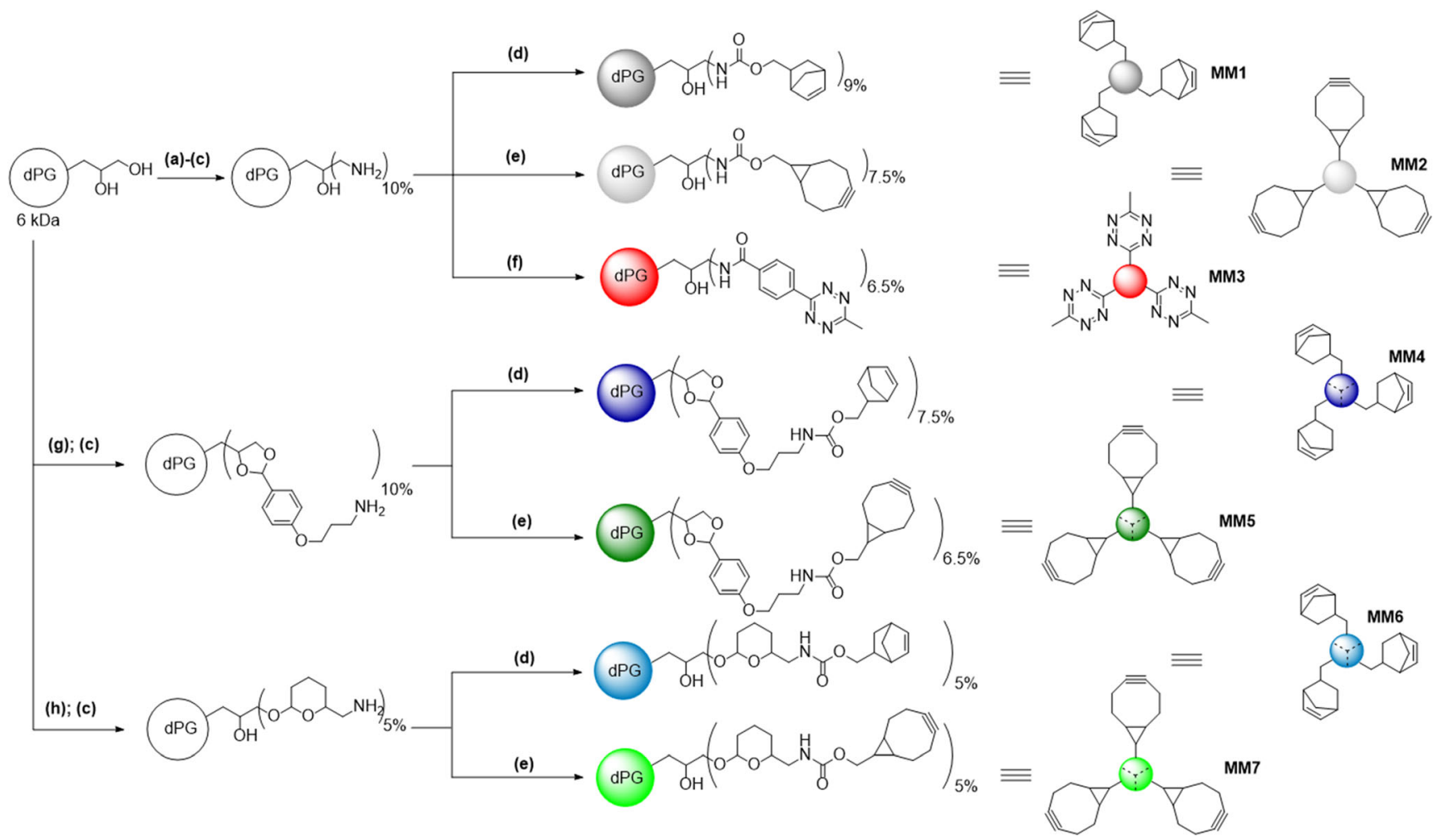

Scheme 1 Synthetic overview for the different macromonomers. The following conditions were used: (a) $\mathrm{MsCl}, \mathrm{NEt}_{3}, \mathrm{DMF}$, rt, overnight; (b) $\mathrm{NaN}_{3}, 6{ }^{\circ} \mathrm{C}, 3$ days; (c) $\mathrm{PPh}_{3}$, water/THF, rt, 3 days; (d) 1, $\mathrm{NEt}_{3}$, DMF, rt, overnight; (e) 2, $\mathrm{NEt}_{3}, \mathrm{DMF}$, rt, overnight; (f) 5, HATU,
DIPEA, DMF, rt, overnight; (g) 1-(3-azidopropoxy)-4(dimethoxymethyl)benzene, pTSA, DMF, $40{ }^{\circ} \mathrm{C}$, overnight; and (h) 3, pTSA, DMF, rt, overnight. Number of reactive groups not representative; just for clearness

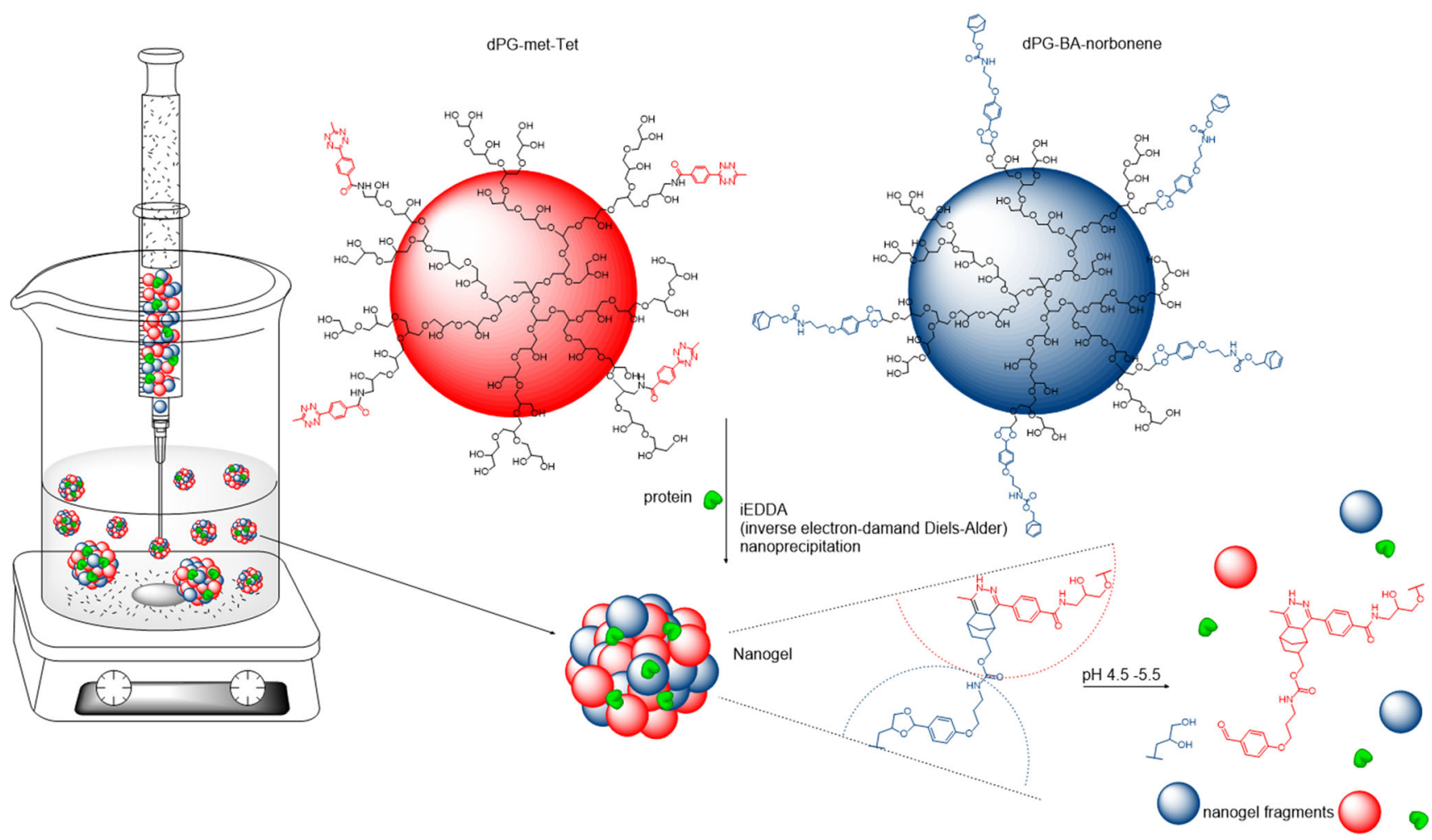

Scheme 2 Simplified overview on the inverse nanoprecipitation process; $\mathrm{pH}$ decrease leads to disintegration of the network and the release of the protein cargo 
Table 1 Influence of water to acetone ratio on the hydrodynamic diameter of dPGBA-norbonene/dPG-metTet-NGs

\begin{tabular}{|c|c|c|c|c|c|}
\hline \multirow[t]{2}{*}{ Entry } & \multicolumn{2}{|c|}{ Macromonomer } & \multirow[t]{2}{*}{$\mathrm{V}\left(\mathrm{H}_{2} \mathrm{O}\right): \mathrm{V}$ (acetone) } & \multirow{2}{*}{$\begin{array}{l}\text { Z-average } \\
(\mathrm{nm})\end{array}$} & \multirow[t]{2}{*}{ PDI } \\
\hline & Ratio (A:B) & $\begin{array}{l}\mathrm{c} \\
(\mathrm{mg} / \mathrm{mL})\end{array}$ & & & \\
\hline 1 & $1: 1.5$ & 5 & $1: 80^{\mathrm{a}}$ & $102 \pm 2$ & $0.03 \pm 0.01$ \\
\hline 2 & $1: 1.5$ & 5 & $1: 60$ & $120 \pm 2$ & $0.02 \pm 0.01$ \\
\hline 3 & $1: 1.5$ & 5 & $1: 40$ & $91 \pm 1$ & $0.04 \pm 0.02$ \\
\hline 4 & $1: 1.5$ & 5 & $1: 20$ & $62 \pm 1$ & $0.08 \pm 0.01$ \\
\hline
\end{tabular}

$\mathrm{A}=\mathrm{dPG}-\mathrm{metTet}$ B $=\mathrm{dPG}-\mathrm{BA}$-norbonene. ${ }^{\mathrm{a}}$ Different container used for gelation compared with other water/ acetone ratios, $T_{\mathrm{q} \text {, chem }}=10 \mathrm{~min}, T_{\mathrm{q}}$, water $=30 \mathrm{~min}$
For background subtraction, also wells containing no cells but only sample were used. After 24-h incubation, the CCK8 solution was added $(10 \mu \mathrm{L} /$ well $)$ and absorbance $(450 \mathrm{~nm} / 650$ $\mathrm{nm}$ ) was measured after approximately 3 -h incubation of the dye using a Tecan plate reader (Infinite pro200, TECANreader Tecan Group Ltd.).

Measurements were performed in triplicate and repeated three times. The cell viability was calculated by setting the non-treated control to $100 \%$ and the non-cell control to $0 \%$ after subtracting the background signal using the Excel software.

\section{Results and discussion}

\section{Synthesis of precursors and macromonomers}

The synthetic accessibility of macromonomers and precursors for nanogel formation is quite important, as any useful application needs scalable and high-yielding reactions. For the inverse nanoprecipitation itself, a highly efficient and bioorthogonal crosslinking chemistry is needed. The iEDDA crosslinking chemistry we used provides the efficient and fast reaction to produce nanogels in a reliable fashion. The synthetic focus of this work thus lies on the synthetic description of the pH-cleavable THP linker that was used, to our knowledge, for the first time and the different macromonomers that were obtained from the dPG-benzacetal- and dPG-THP-amine cores.

The second most important property for a biological application is the biocompatibility of the synthetic polymers that are used. Dendritic polyglycerol is a platform for straightforward post-modification and has already been shown to be biocompatible [53]. The polymer itself can be obtained on a multigram to kilogram scale and is easy to functionalize either directly via the hydroxyl groups or by a short reaction sequence that leads to the dPG-amine derivative. This dPGamine can then be reacted with a large variety of molecules to further introduce functionality to the polymer. In this way, many different non-degradable macromonomers for iEDDA can be generated in a straightforward and scalable fashion.

The synthetic routes for the activated carbonates of the dienophiles $(\mathbf{1}+\mathbf{2})$, the methyl tetrazine carboxylic acid (3), the benzacetal-azide precursor (4), and the DHP-azide (5) can be found in Scheme S1 in the Supporting information. These precursors were then used to functionalize $\mathrm{dPG}$, as well as dPG-amine to the corresponding macromonomers that were used in this work. The synthetic routes are described in Scheme 1.

Norbonene was chosen as the reactive dienophile because its activated carbonate form can be obtained in a high-yielding two-step reaction from the commercially available and quite inexpensive precursor bicyclo[2.2.1]hept-5-ene-2carbaldehyde. The methyl tetrazine carboxylic acid (3) has also been shown to be easily attached to the dPG-amine core
Table 2 Influence of water to acetone ratio on the hydrodynamic diameter of dPGBA-BCN/dPG-metTet-NGs

\begin{tabular}{|c|c|c|c|c|c|}
\hline \multirow[t]{2}{*}{ Entry } & \multicolumn{2}{|c|}{ Macromonomer } & \multirow[t]{2}{*}{$\mathrm{V}\left(\mathrm{H}_{2} \mathrm{O}\right): \mathrm{V}$ (acetone) } & \multirow{2}{*}{$\begin{array}{l}\text { Z-average } \\
(\mathrm{nm})\end{array}$} & \multirow[t]{2}{*}{ PDI } \\
\hline & Ratio (A:B) & $\begin{array}{l}\mathrm{c} \\
(\mathrm{mg} / \mathrm{mL})\end{array}$ & & & \\
\hline 1 & $1: 1.5$ & 5 & $1: 80^{\mathrm{a}}$ & $94 \pm 1$ & $0.06 \pm 0.01$ \\
\hline 2 & $1: 1.5$ & 5 & $1: 60$ & $147 \pm 2$ & $0.10 \pm 0.01$ \\
\hline 3 & $1: 1.5$ & 5 & $1: 40$ & $88 \pm 1$ & $0.07 \pm 0.01$ \\
\hline 4 & $1: 1.5$ & 5 & $1: 20$ & $47 \pm 1$ & $0.10 \pm 0.01$ \\
\hline
\end{tabular}

$\mathrm{A}=\mathrm{dPG}-\mathrm{metTet} ; \mathrm{B}=\mathrm{dPG}-\mathrm{BA}-\mathrm{BCN} .{ }^{\mathrm{a}}$ Different container used for gelation compared with other water/acetone ratios, $T_{\mathrm{q} \text {, chem }}=10 \mathrm{~min}, T_{\mathrm{q} \text {, water }}=30 \mathrm{~min}$ 
Fig. 1 Size trend and polydispersity of nanogels formed from MM4 and MM5 with varying water to acetone ratio during inverse nanoprecipitation

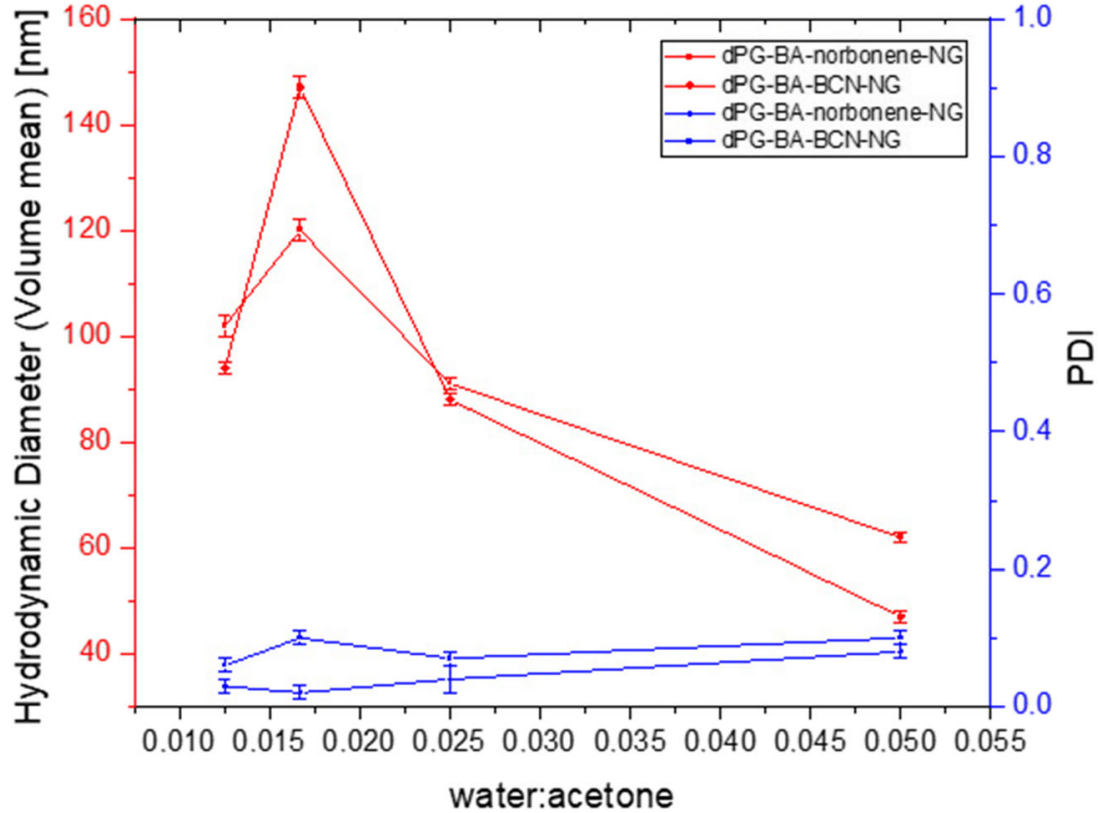

form the cyclic aromatic acetal motif that can be seen in Scheme 1. The precursor for the aliphatic acetal linking groups can be obtained by modification of a common protecting group for alcohols in organic synthesis, the DHP protecting group. A slightly modified precursor is commercially available $((3,4-$ dihydro-2H-pyran-2-yl)methanol). This was transformed in two steps to the corresponding DHP-azide (5) which was then attached to the dPG-core by an acid catalyzed addition reaction.

The polymer azides that were obtained in this fashion were then reduced to the corresponding amines, using a Staudinger reduction. The dPG-acetal amines are the platform for the attachment of the activated carbonate forms of the dienophiles. These dPG-acetal-dienophiles (MM4-MM7) were obtained in high yields of 85 to $>99 \%$ applying the same synthetic method for each macromonomer. This toolbox of monomers was then characterized using NMR, IR, and DLS. The degradable macromonomers were then employed to produce nanogels via inverse nanoprecipitation in acetone.

Table 4 Influence of water quenching time on the hydrodynamic diameter of dPG-BA-BCN/dPG-metTet-NGs

\begin{tabular}{|c|c|c|c|c|c|}
\hline \multirow[t]{2}{*}{ Entry } & \multicolumn{2}{|c|}{ Macromonomer } & \multirow{2}{*}{$\begin{array}{l}T_{\mathrm{q}, \text { water }} \\
\text { (min) }\end{array}$} & \multirow{2}{*}{$\begin{array}{l}\text { Z-average } \\
(\mathrm{nm})\end{array}$} & \multirow[t]{2}{*}{ PDI } \\
\hline & Ratio (A:B) & $\begin{array}{l}\mathrm{c} \\
(\mathrm{mg} / \mathrm{mL})\end{array}$ & & & \\
\hline 1 & $1: 1.5$ & 5 & 30 & $73 \pm 1$ & $0.08 \pm 0.01$ \\
\hline 2 & $1: 1.5$ & 5 & 40 & $65 \pm 1$ & $0.07 \pm 0.01$ \\
\hline 3 & $1: 1.5$ & 5 & 50 & $62 \pm 1$ & $0.10 \pm 0.01$ \\
\hline 4 & $1: 1.5$ & 5 & 60 & $72 \pm 1$ & $0.07 \pm 0.01$ \\
\hline
\end{tabular}



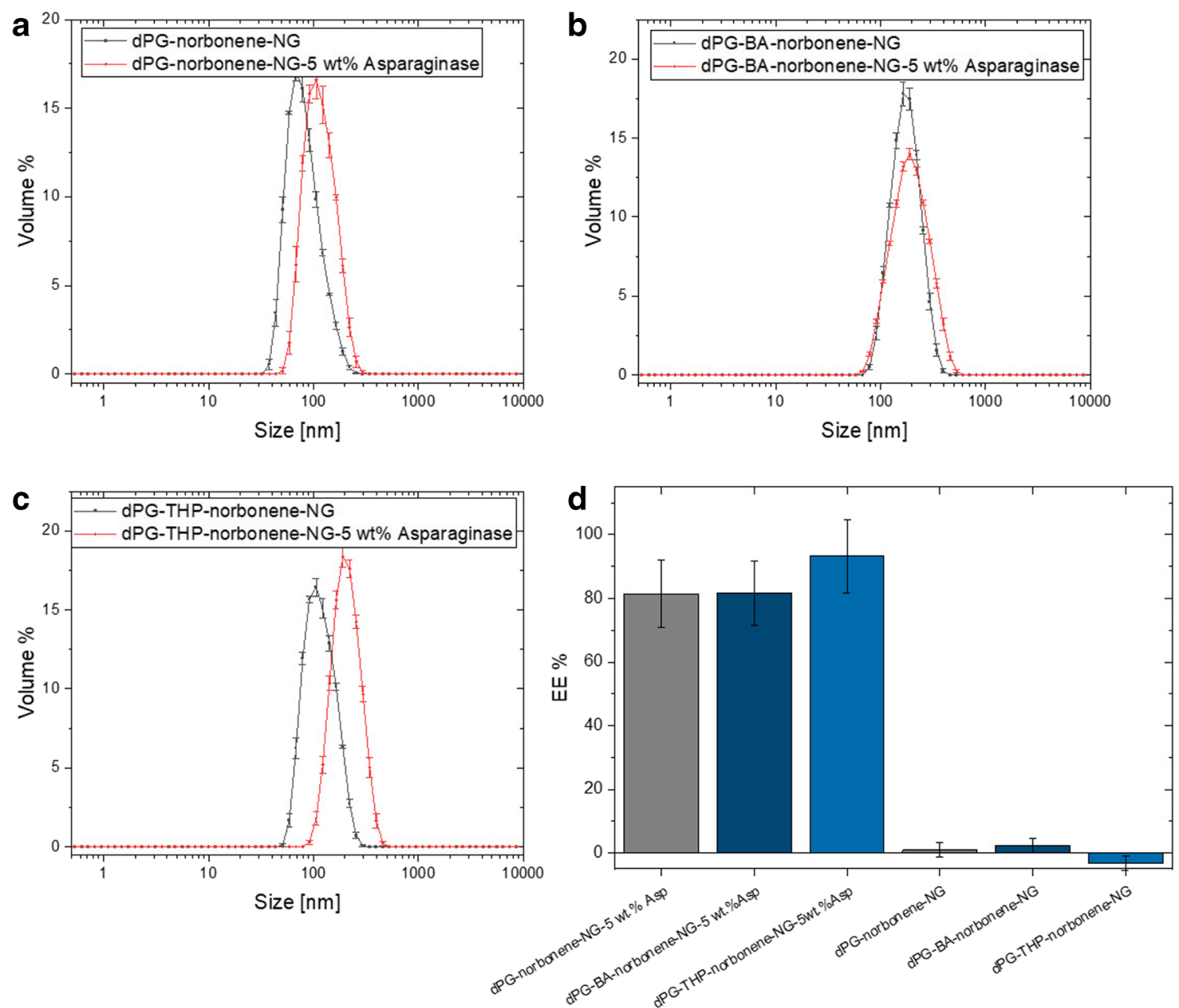

Fig. 2 Co-precipitation of asparaginase at 5 wt.\% feed with MM1/MM3, MM4/MM3, and MM6/MM3. a DLS data for a gel without (black) and with asparaginase (red) present during gel formation (dPG-norboneneNG). b DLS data for a gel without (black) and with asparaginase (red) present during gel formation (dPG-BA-norbonene-NG). $\mathbf{c}$ DLS data for a

\section{Nanogel preparation by inverse nanoprecipitation}

In general, the inverse nanoprecipitation method works by injection of a solution of macromonomers in a suitable solvent, such as water, into the corresponding non-solvent of said macromonomers, in this case acetone. While the water is dispersed within the acetone, the insoluble macromonomers precipitate out of solution. First small aggregates are formed which, with time, form larger and larger conglomerates. Due to the local concentration of these macromonomers within the aggregates being high, the reaction of the dienophiles with methyl tetrazin proceeds very fast and thus leads to the crosslinking of the aggregates to form a hydrophilic nanogel network. As time proceeds, the small gel networks come into contact and crosslink further until almost all macromonomers are consumed, yielding the stable dispersions of nanogels acetone. By the addition of water, the gel formation is quenched, and upon removal of acetone, the nanogels are obtained as stable dispersions in water. gel without (black) and with asparaginase (red) present during gel formation (dPG-THP-norbonene-NG). d Encapsulation efficiency determined by a BCA assay for gels with asparaginase and control gels without; the readout of the control gels was subtracted from the values that were determined for the gels containing asparaginase

The simplified process can be seen in Scheme 2 with dPG-BAnorbonene and dPG-metTet as an example.

We studied the parameters that have the most influence on nanogel formation with this type of macromonomers. It was observed that the time when water is added to the reaction mixture and the water/acetone ratio are the most influential parameters on nanogel size.

As can be seen in Tables 1 and 2, we investigated the influence of water to acetone ratios on nanogel size and polydispersity for dPG-BA-norbonene and dPG-BA-BCN nanogels, respectively.

The overall trend is summarized in Fig. 1.

It is evident that there is a trend towards smaller nanogels when the ratio of water to acetone becomes bigger. This is expected, as a higher water content increases the solubility of the macromonomers in the mixture of water and acetone, thus leading to smaller aggregates in the non-solvent. The ratio of 0.0125 , however, is an outlier since more than one parameter 

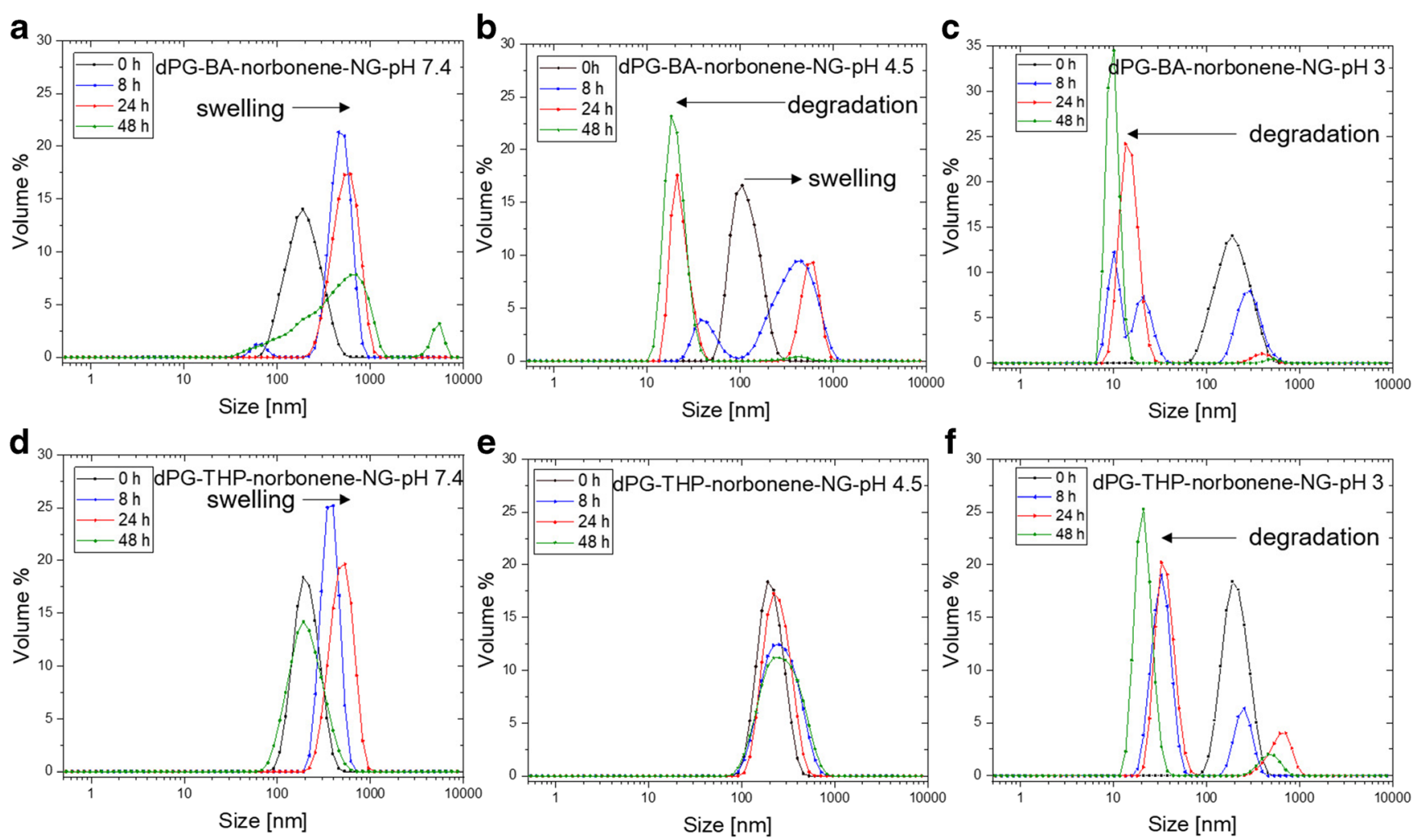

Fig. 3 Degradation profiles of dPG-BA-norbonene- and dPG-THP-norbonene at $\mathrm{pH} 7.4, \mathrm{pH} 4.5$, and $\mathrm{pH}$ 3. a-c dPG-BA-norbonene-NG at $\mathrm{pH}$ 7.4, 4.5, and 3. d-f dPG-THP-NG at $\mathrm{pH} 7.4,4.5$, and 3

was changed. Instead of only changing the solvent to nonsolvent ratio, the geometry and total volume of the container was altered at the same time $(250 \mathrm{~mL}$ instead of $80 \mathrm{~mL})$. Two significant parameters are altered and thus lead to the outlying point in the trend line. However, for a given set of parameters, the nanogel production is reproducible. Moreover, the polydispersity of the final nanogels in water is not significantly influenced by the high ratios of water:acetone which offers the opportunity to produce small nanogels without a negative impact on the polydispersity of the gels and using relatively low amounts of organic solvent, which simplifies the overall process of nanogel production.

The second most influencing parameter we tested was the time when water was added to the mixture in order to stop any further crosslinking between already formed nanoaggregates. The results for a variety of quenching times between 4 and $60 \mathrm{~min}$ are shown for dPG-BA-norbonene/dPG-metTet in Table 3.

One can see that immediate quenching after 4 or $5 \mathrm{~min}$ leads to a complete disruption of nanogel formation as the resulting gel/macromonomer mixtures were so polydisperse that they did not reach the measurement quality to report a reliable value. After $10 \mathrm{~min}$, the gel seemed to have formed; however, the polydispersity was quite high compared with other batches, which indicates that at this timepoint there are still unreacted small aggregates present. After around $30 \mathrm{~min}$, the gel is fully formed and no significant change in nanogel size can be observed. The polydispersity, however, reaches very good values of below 0.05 .

We decided to test only larger quenching times for MM5 as it was evident that a real control over nanogel size using small quenching times was not possible. The results for quenching times between 30 and $60 \mathrm{~min}$ are summarized in Table 4 .

As expected, the longer quenching times did not have an influence on nanogel size as most of the crosslinking happened in the first few minutes. However, it also showed that most of the reactive surface groups were consumed within the first hour, which prevented bigger aggregates and possibly complete precipitation of the nanogels. PDI values were also not significantly affected using these quenching times and stayed between 0.07 and 0.1 .

The nanogels were obtained in a reproducible manner. We thus chose the norbonene derivative to perform coprecipitation of the therapeutic protein asparaginase.

\section{Asparaginase encapsulation by co-precipitation}

The protein asparaginase is used as a drug to treat acute lymphoblastic leukemia (ALL). A PEGylated version is available on the market (Oncaspar®) [3].

5 wt.\% of protein compared with the total amount of macromonomers was chosen for encapsulation, without severely impacting the polydispersity of the gels. However, the size of the nanogels almost always increased to higher 

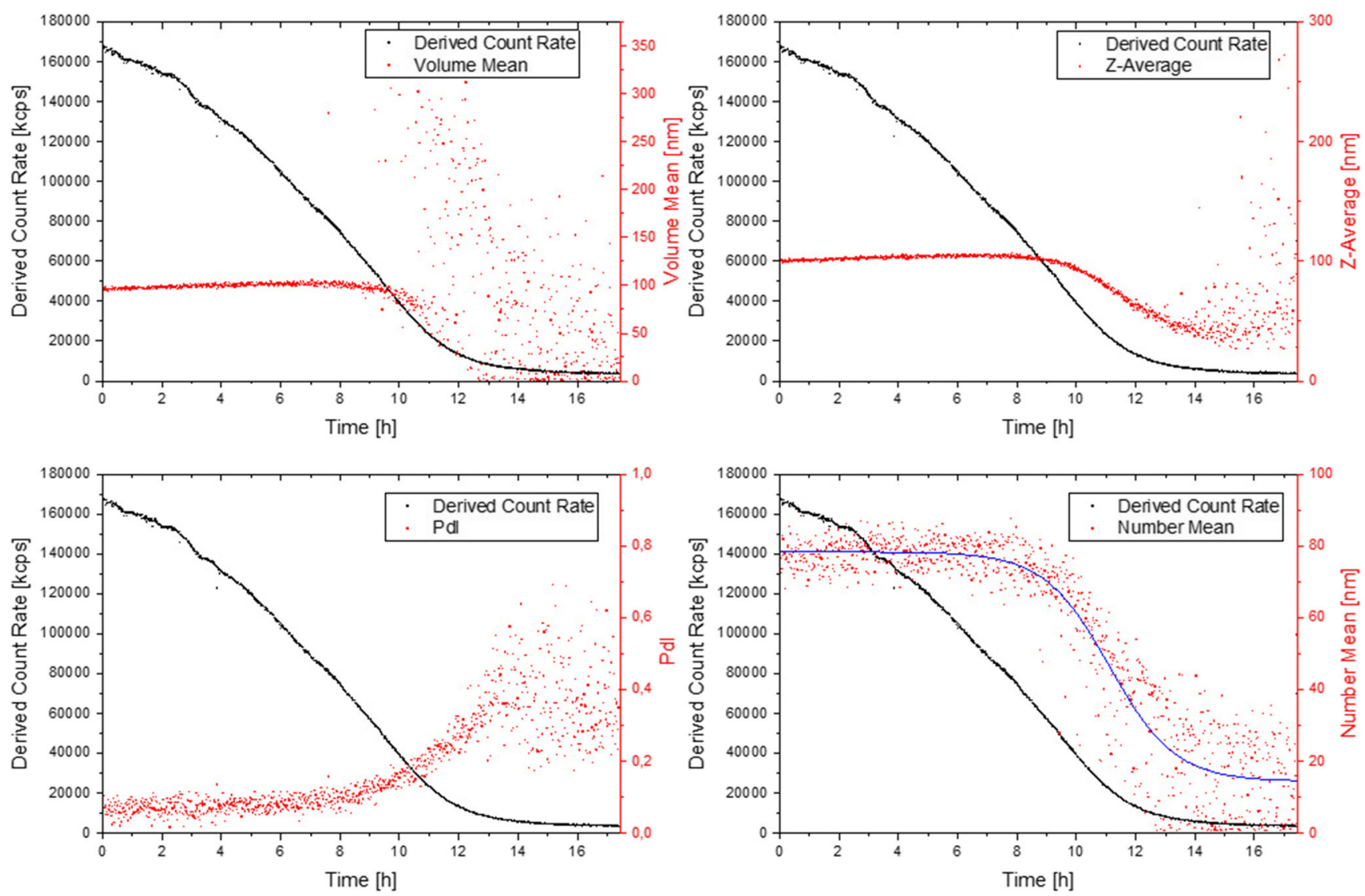

Fig. 4 Continuous degradation profile of dPG-BA-norbonene-NG at pH 4.5 in acetate buffer. Size by volume, Z-average, size by number, and PDI are shown. The derived count rate is shown for comparison

values when compared with gels that were produced without the addition of a protein.

The norbonene derivatives of the macromonomers (MM1, MM4, MM6) were used to perform the co-precipitation of asparaginase, as the precursors are synthetically more accessible compared with the $\mathrm{BCN}$ derivatives and should have negligible reactivity towards biological systems. As a control we used nanogels that were prepared without the addition of asparaginase during nanoprecipitation. The results are summarized in Fig. 2.

It is evident that the co-precipitation of a protein shifted the size of the resulting nanogels to higher values. We hypothesize that this was due to interactions of the protein with the macromonomers during the inverse nanoprecipitation process which lead to the formation of bigger initial aggregates which grew faster during the gel formation process, thus resulting in bigger nanogels.

After a purification process, where the gels were washed in a centrifugal filter with PBS, most of any free protein should be removed from the gel dispersions. The gels were then tested regarding their protein content, using a standard BCA assay with a dilution series of free asparaginase as the standard curve (Figure S4). Gels that were formed without the addition of asparaginase were used as a control, and the OD values for these gels were subtracted from the gels that contained asparaginase. The results of the encapsulation efficiency can be seen in Fig. 2d. All three types of gels, namely dPGnorbonene, dPG-BA-norbonene-, and dPG-THP-norbonene nanogels, reached very good encapsulation efficiencies of between 81 and $93 \%$, showing the suitability of these macromonomers to form gels that efficiently entrap asparaginase within their gel network.

The $\mathrm{pH}$ degradability of the different types of acetal functionalized nanogels was then tested at different $\mathrm{pH}$ values.

\section{pH-triggered degradation of nanogels}

In order to study the degradation behavior of the gels, we added the different types of gels which contained asparaginase to buffer at different $\mathrm{pH}$ values. Every group of gel was exposed to $\mathrm{pH} 7.4, \mathrm{pH} 4.5$, and $\mathrm{pH} 3$ at moderate agitation and room temperature. The degradation was then followed over the course of $48 \mathrm{~h}$. At each time point a sample was taken and snap frozen in liquid nitrogen to be later measured by DLS. The results are shown in Fig. 3 and Figure S8.

At pH 7.4 (Fig. 3a, d) both gels do not show degradation at all. Through the strong agitation, however, the particles tend to aggregate and show a strong increase in polydispersity. In terms of degradation, there was no significant amount of small 


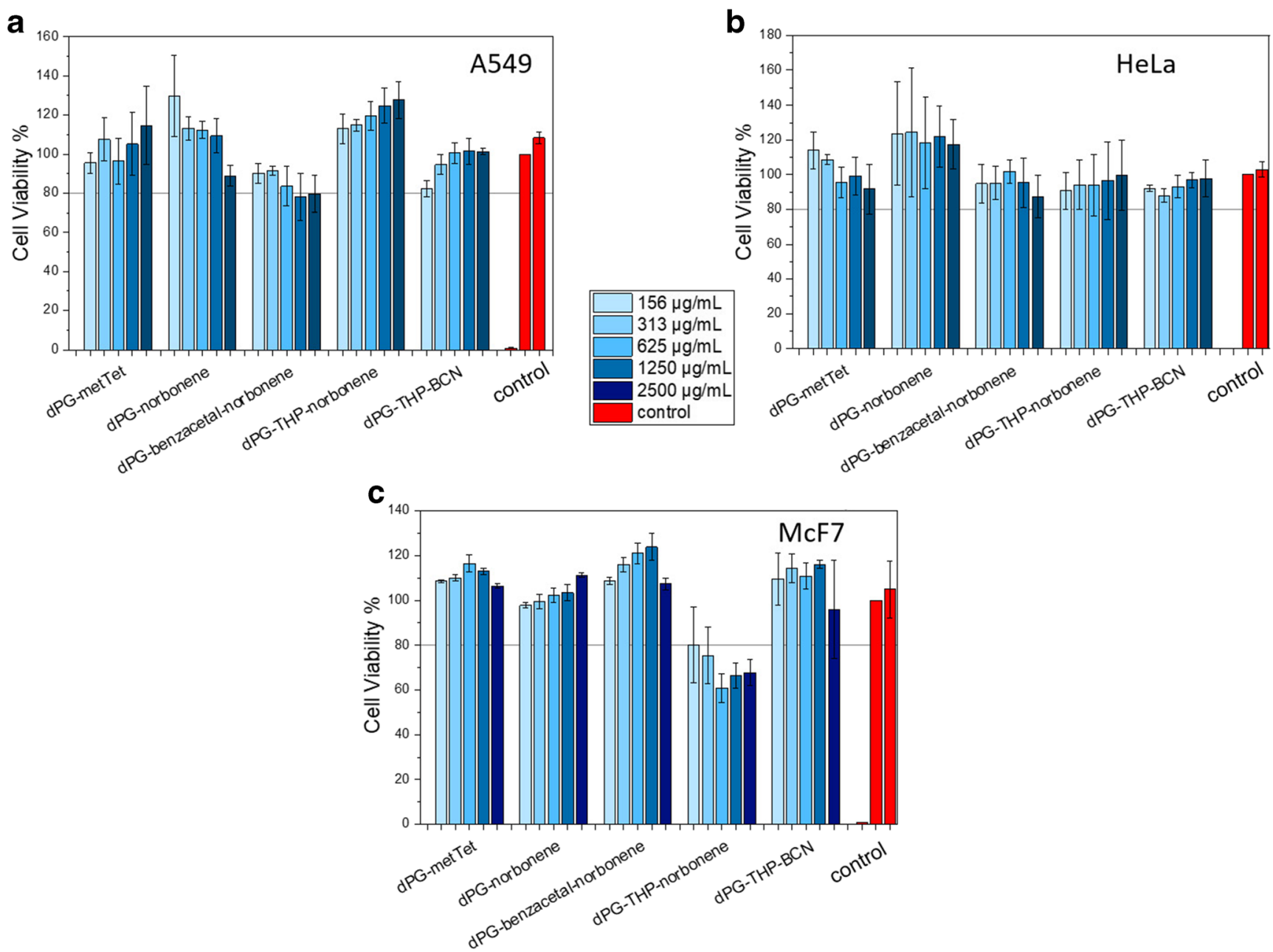

Fig. 5 Cell viability assay of all different macromonomers using three different cell lines, control: from left to right SDS (1\%), medium (10\%), water (10\%). a A549 cell line. b HeLa cell line. c McF7 cell line

particles observable. However, at $\mathrm{pH} 4.5$ nanogel degradation was observed for the gel with BA linking groups (Fig. 3b). At first, swelling of the nanogels was observed, which shifted the distribution towards bigger size values, while only after $24 \mathrm{~h}$ small particles appeared at around $20 \mathrm{~nm}$ in a mix with still intact nanogels. After $48 \mathrm{~h}$, however, most particles were in the size range of around $20 \mathrm{~nm}$. In contrast, even after $48 \mathrm{~h}$ no degradation was observed for the aliphatic THP-acetal linker containing gel (Fig. 3e). This was expected, as these kinds of acetals degrade usually only at $\mathrm{pH}$ values of below 3 .

At $\mathrm{pH}$ 3, the dPG-BA-norbonene NG (Fig. 3c) degraded much faster than at $\mathrm{pH} 4.5$. After already $3 \mathrm{~h}$ particles of around $50 \mathrm{~nm}$ were observed and after $8 \mathrm{~h}$ mostly particles of around $20 \mathrm{~nm}$ remained. At $48 \mathrm{~h}$ nearly all particles were degraded to around $10 \mathrm{~nm}$, which signaled the complete breakdown of the gels into mostly macromonomers.

The dPG-THP-norbonene-NG at $\mathrm{pH} 3$ in contrast to $\mathrm{pH} 4.5$ started to degrade and showed smaller particles of around $50 \mathrm{~nm}$ after $8 \mathrm{~h}$. After $48 \mathrm{~h}$ almost complete degradation to particles of around $20 \mathrm{~nm}$ was observed.
In order to see a more detailed degradation profile of the $\mathrm{dPG}$ BA-norbonene-NGs, a continuous monitoring over the course of $18 \mathrm{~h}$ was performed. For this, a nanogel without protein was degraded in acetate buffer at $\mathrm{pH} 4.5$ within a DLS cuvette and measured continuously while every measurement corresponds to roughly $2 \mathrm{~min}$. The results are shown in Fig. 4.

The black curve in every diagram corresponds to the derived count rate. This was constantly decreasing over time, which indicated less, and less particle counts over time. However, over a long period of time of around 8 to $9 \mathrm{~h}$, not much change could be observed in the volume and number distributions. If at all, there is a slight increase in size, probably due to swelling of the gels. After around $9 \mathrm{~h}$, the PDI value slowly started to rise, which showed that a mixture of particles must be present with a wider distribution of sizes. This could also be observed in the size by volume and number distributions. From this point on, the size values continued to decrease until at around $13 \mathrm{~h}$ the count rate became too low for the measurement quality to obtain reliable results. This was indicated by the fluctuation of measurement values and the strong 
spreading of the distribution of values. However, at least a trend could be observed, which showed that the gels disintegrated between 9 and $14 \mathrm{~h}$ to values below $20 \mathrm{~nm}$.

All in all, this shows that the gels based on the BA linkers that were used can be degraded at $\mathrm{pH}$ values that can be found in endosomes and lysosomes. At pH 7.4 all gels were stable for extended periods of time, as can be seen in Figure S6. NTA measurements of the same gels also confirmed that the particle sizes obtained from DLS are comparable (Figure S7).

\section{CCK8 cell viability test}

For any application handling living cells or in vivo experiments, it is necessary to know if the macromonomers that are used are non-toxic to the cells at reasonable concentrations. In the case of the nanogels we presented here, no free macromonomers remain; however, for applications such as microgelation and co-encapsulation of living cells, it is absolutely mandatory to see if the macromonomers are toxic, because they come into direct contact with the cells they encapsulate. After gel formation the gels are mostly appearing as hydrophilic networks, presenting a lot of hydroxyl groups and it has been demonstrated before that nanogels, based on $\mathrm{dPG}$, do not impact the cell viability negatively within a certain concentration range [55].

The results for three different cell lines are summarized in Fig. 5.

All macromonomers did not have a big impact on cell viability up to approximately a concentration of $156 \mu \mathrm{g}$ $\mathrm{mL}^{-1}$; however, dPG-THP-norbonene exhibited slight cytotoxicity at concentrations higher than this. The rest of the macromonomers were non-toxic even up to concentrations of $2.5 \mathrm{mg} \mathrm{mL}^{-1}$. This indicated that the macromonomers are suitable even for applications with living cells.

\section{Conclusion}

We have shown the synthesis of different reactive macromonomers for iEDDA click chemistry mediated production of $\mathrm{pH}$-degradable nanogels that are degraded at their acetal linking points. Three different groups of nanogels were produced. Non-degradable gels, degradable gels, based on an aromatic BA linker, and degradable gels based on an aliphatic THP acetal were obtained. The NGs were synthesized in the size range of 47-200 $\mathrm{nm}$ with excellent polydispersity indices of 0.1 and below.

Co-precipitation of the therapeutic protein asparaginase showed excellent encapsulation efficiencies of between 81 and $93 \%$ for nanogels made from dPG-norbonene and dPGBA-norbonene, respectively.

Gels based on the aromatic BA linker were degraded at $\mathrm{pH}$ values of 4.5 , within $24 \mathrm{~h}$, while THP-linked gels were not degraded at all at this $\mathrm{pH}$. dPG-BA-norbonene gels were degraded fast within $9 \mathrm{~h}$ at $\mathrm{pH} \mathrm{3}$, and dPG-THP gels showed complete degradation within $24 \mathrm{~h}$ at this $\mathrm{pH}$ showing the applicability of the dPG-BA-dienophile gels for degradation within endosomal to lysosomal $\mathrm{pH}$ windows. All gels were stable in PBS at $\mathrm{pH} 7.4$ for extended periods of time. The macromonomers used did not show cell toxic effects up to about $2.5 \mathrm{mg} \mathrm{mL}^{-1}$, except for dPGTHP-norbonene.

The low toxicity of the macromonomers, as well as the reproducible gel formation within a reasonable size range and low polydispersity, together with the excellent encapsulation efficiency, makes the nanogels ideal for the delivery of therapeutic proteins. As a future perspective, functionalization of the dPG-core with targeting ligands could be performed, in order to obtain nanocarriers that have active as well as passive targeting properties.

Acknowledgments We like to acknowledge Cathleen Schlesener for providing $\mathrm{dPG}$ and $\mathrm{dPG}-\mathrm{NH}_{2}$ and the BioSupraMol core facility for NMR measurements. Elisa Quaas is thanked for performing the CCK8 assay and Dr. Pamela Winchester is thanked for careful proofreading this manuscript.

Funding information Open Access funding provided by Projekt DEAL. The study was financially supported by the SFB 765 of the German Science Foundation (Deutsche Forschungsgemeinschaft, DFG).

\section{Compliance with ethical standards}

Conflict of interest The authors declare that they have no conflict of interest.

Open Access This article is licensed under a Creative Commons Attribution 4.0 International License, which permits use, sharing, adaptation, distribution and reproduction in any medium or format, as long as you give appropriate credit to the original author(s) and the source, provide a link to the Creative Commons licence, and indicate if changes were made. The images or other third party material in this article are included in the article's Creative Commons licence, unless indicated otherwise in a credit line to the material. If material is not included in the article's Creative Commons licence and your intended use is not permitted by statutory regulation or exceeds the permitted use, you will need to obtain permission directly from the copyright holder. To view a copy of this licence, visit http://creativecommons.org/licenses/by/4.0/.

\section{References}

1. Ruiz-Garcia A, Bermejo M, Moss A, Casabo VG (2008) Pharmacokinetics in drug discovery. J Pharm Sci 97:654-690. https://doi.org/10.1002/jps.21009

2. Raemdonck K, Demeester J, De Smedt S (2009) Advanced nanogel engineering for drug delivery. Soft Matter 5:707-715. https://doi. org/10.1039/b811923f

3. Farjadian F, Ghasemi A, Gohari O, Roointan A, Karimi M, Hamblin MR (2019) Nanopharmaceuticals and nanomedicines currently on the market: challenges and opportunities. Nanomedicine 14:93-126. https://doi.org/10.2217/nnm-2018-0120

4. Choi YH, Han HK (2018) Nanomedicines: current status and future perspectives in aspect of drug delivery and pharmacokinetics. J Pharm Investig 48:43-60. https://doi.org/10.1007/s40005-017-0370-4 
5. Jiskoot W, Randolph TW, Volkin DB, Russell Middaugh C, Schöneich C, Winter G, Friess W, Crommelin DJA, Carpenter JF (2012) Protein instability and immunogenicity: roadblocks to clinical application of injectable protein delivery systems for sustained release. J Pharm Sci 101:946-954. https://doi.org/10.1002/jps.23018

6. Alexis F, Pridgen E, Molnar LK, Farokhzad OC (2008) Factors affecting the clearance and biodistribution of polymeric nanoparticles. Mol Pharm 5:505-515. https://doi.org/10.1021/mp800051m

7. Dobrovolskaia MA, Neun BW, Man S, Ye X, Hansen M, Patri AK, Crist RM, McNeil SE (2014) Protein corona composition does not accurately predict hematocompatibility of colloidal gold nanoparticles. Nanomed Nanotechnol Biol Med 10:1453-1463. https://doi. org/10.1016/j.nano.2014.01.009

8. Gröger D, Kerschnitzki M, Weinhart M, Reimann S, Schneider T, Kohl B, Wagermaier W, Schulze-Tanzil G, Fratzl P, Haag R (2014) Selectivity in bone targeting with multivalent dendritic polyanion dye conjugates. Adv Healthc Mater 3:375-385. https://doi.org/10. 1002/adhm.201300205

9. Seymour LW, Duncan R, Strohalm J, Kopeček J (1987) Effect of molecular weight (Mw) ofN-(2-hydroxypropyl)methacrylamide copolymers on body distribution and rate of excretion after subcutaneous, intraperitoneal, and intravenous administration to rats. J Biomed Mater Res 21:1341-1358. https://doi.org/10.1002/jbm.820211106

10. Haag R, Kratz F (2006) Polymer therapeutics: concepts and applications. Angew Chem Int Ed 45:1198-1215. https://doi.org/10. 1002/anie.200502113

11. Greenwald RB, Choe YH, McGuire J, Conover CD (2003) Effective drug delivery by PEGylated drug conjugates. Adv Drug Deliv Rev 55: 217-250. https://doi.org/10.1016/S0169-409X(02)00180-1

12. Thomas A, Müller SS, Frey H (2014) Beyond Poly(ethylene glycol): linear polyglycerol as a multifunctional polyether for biomedical and pharmaceutical applications. Biomacromolecules 15: 1935-1954. https://doi.org/10.1021/bm5002608

13. Baca QJ, Leader B, Golan DE (2017) Protein therapeutics. Springer International Publishing, Cham

14. Turecek PL, Bossard MJ, Schoetens F, Ivens IA (2016) PEGylation of biopharmaceuticals: a review of chemistry and nonclinical safety information of approved drugs. J Pharm Sci 105:460-475. https:// doi.org/10.1016/j.xphs.2015.11.015

15. Zhang P, Sun F, Liu S, Jiang S (2016) Anti-PEG antibodies in the clinic: current issues and beyond PEGylation. J Control Release 244:184-193. https://doi.org/10.1016/j.jconrel.2016.06.040

16. Singh S, Topuz F, Hahn K, Albrecht K, Groll J (2013) Embedding of active proteins and living cells in redox-sensitive hydrogels and nanogels through enzymatic cross-linking. Angew Chem Int Ed 52: 3000-3003. https://doi.org/10.1002/anie.201206266

17. Chacko RT, Ventura J, Zhuang J, Thayumanavan S (2012) Polymer nanogels: a versatile nanoscopic drug delivery platform. Adv Drug Deliv Rev 64:836-851. https://doi.org/10.1016/j.addr.2012.02.002

18. Karg M, Pich A, Hellweg T, Hoare T, Lyon LA, Crassous JJ, Suzuki D, Gumerov RA, Schneider S, Potemkin II, Richtering W (2019) Nanogels and microgels: from model colloids to applications, recent developments, and future trends. Langmuir 35:62316255. https://doi.org/10.1021/acs.langmuir.8b04304

19. Sivaram AJ, Rajitha P, MayaS, Jayakumar R, Sabitha M(2015) Nanogels for delivery, imaging and therapy. Wiley Interdiscip Rev Nanomed Nanobiotechnol 7:509-533. https://doi.org/10.1002/wnan.1328

20. Ekkelenkamp AE, Elzes MR, Engbersen JFJ, Paulusse JMJ (2018) Responsive crosslinked polymer nanogels for imaging and therapeutics delivery. J Mater Chem B 6:210-235. https://doi.org/10. 1039/C7TB02239E

21. Kabanov AV, Vinogradov SV (2009) Nanogels as pharmaceutical carriers: finite networks of infinite capabilities. Angew Chem Int Ed 48:5418-5429. https://doi.org/10.1002/anie.200900441

22. Bazban-Shotorbani S, Dashtimoghadam E, Karkhaneh A, HasaniSadrabadi MM, Jacob KI (2016) Microfluidic directed synthesis of alginate nanogels with tunable pore size for efficient protein delivery. Langmuir 32:4996-5003. https://doi.org/10.1021/acs. langmuir.5b04645

23. Klinger D, Landfester K (2012) Enzymatic- and light-degradable hybrid nanogels: crosslinking of polyacrylamide with acrylate-functionalized Dextrans containing photocleavable linkers. J Polym Sci Part A Polym Chem 50:1062-1075. https://doi.org/10.1002/pola.25845

24. Thomann-Harwood LJ, Kaeuper P, Rossi N, Milona P, Herrmann B, McCullough KC (2013) Nanogel vaccines targeting dendritic cells: contributions of the surface decoration and vaccine cargo on cell targeting and activation. J Control Release 166:95-105. https:// doi.org/10.1016/j.jconrel.2012.11.015

25. Gratton SEA, Pohlhaus PD, Lee J, Guo J, Cho MJ, DeSimone JM (2007) Nanofabricated particles for engineered drug therapies: a preliminary biodistribution study of PRINT ${ }^{\mathrm{TM}}$ nanoparticles. J Control Release 121:10-18. https://doi.org/10.1016/j.jconrel.2007.05.027

26. Modi S, Anderson BD (2013) Determination of drug release kinetics from nanoparticles: overcoming pitfalls of the dynamic dialysis method. Mol Pharm 10:3076-3089. https://doi.org/10.1021/mp400154a

27. Dey P, Bergmann T, Cuellar-Camacho JL, Ehrmann S, Chowdhury MS, Zhang M, Dahmani I, Haag R, Azab W (2018) Multivalent flexible nanogels exhibit broad-spectrum antiviral activity by blocking virus entry. ACS Nano 12:6429-6442. https://doi.org/ 10.1021/acsnano.8b01616

28. Witting M, Molina M, Obst K, Plank R, Eckl KM, Hennies HC, Calderón M, Frieß W, Hedtrich S (2015) Thermosensitive dendritic polyglycerol-based nanogels for cutaneous delivery of biomacromolecules. Nanomedicine 11:1179-1187. https://doi.org/ 10.1016/j.nano.2015.02.017

29. Wu C, Böttcher C, Haag R (2015) Enzymatically crosslinked dendritic polyglycerol nanogels for encapsulation of catalytically active proteins. Soft Matter 11:972-980. https://doi.org/10.1039/C4SM01746C

30. Steinhilber D, Witting M, Zhang X, Staegemann M, Paulus F, Friess W, Küchler S, Haag R (2013) Surfactant free preparation of biodegradable dendritic polyglycerol nanogels by inverse nanoprecipitation for encapsulation and release of pharmaceutical biomacromolecules. J Control Release 169:289-295. https://doi. org/10.1016/j.jconrel.2012.12.008

31. Seidi F, Jenjob R, Crespy D (2018) Designing smart polymer conjugates for controlled release of payloads. Chem Rev 118:39654036. https://doi.org/10.1021/acs.chemrev.8b00006

32. Zhang J, Jia Y, Li X, Hu Y, Li X (2011) Facile engineering of biocompatible materials with $\mathrm{pH}$-modulated degradability. Adv Mater 23:3035-3040. https://doi.org/10.1002/adma.201100679

33. Chen W, Hou Y, Tu Z, Gao L, Haag R (2017) pH-degradable PVAbased nanogels via photo-crosslinking of thermo-preinduced nanoaggregates for controlled drug delivery. J Control Release 259:160-167. https://doi.org/10.1016/j.jconrel.2016.10.032

34. Yang H, Wang Q, Chen W, Zhao Y, Yong T, Gan L, Xu H, Yang X (2015) Hydrophilicity/hydrophobicity reversable and redoxsensitive nanogels for anticancer drug delivery. Mol Pharm 150409150353009:1636-1647. https://doi.org/10.1021/acs. molpharmaceut.5b00068

35. Pang X, Jiang Y, Xiao Q, Leung AW, Hua H, Xu C (2016) pHresponsive polymer-drug conjugates: design and progress. J Control Release 222:116-129. https://doi.org/10.1016/j.jconrel.2015.12.024

36. Mauri E, Perale G, Rossi F (2018) Nanogel functionalization: a versatile approach to meet the challenges of drug and gene delivery. ACS Appl Nano Mater 1:6525-6541. https://doi.org/10.1021/acsanm.8b01686

37. O’Donnell JM (2012) Reversible addition-fragmentation chain transfer polymerization in microemulsion. Chem Soc Rev 41: 3061-3076. https://doi.org/10.1039/c2cs15275d

38. Antonietti M, Landfester K, Willert M et al (2001) Polyreactions in non-aqueous miniemulsions. Prog Polym Sci 27:689-757 
39. Hamidi M, Azadi A, Rafiei P (2008) Hydrogel nanoparticles in drug delivery. Adv Drug Deliv Rev 60:1638-1649. https://doi. org/10.1016/j.addr.2008.08.002

40. Schubert S, Delaney Jr JT, Schubert US (2011) Nanoprecipitation and nanoformulation of polymers: from history to powerful possibilities beyond poly(lactic acid). Soft Matter 7:1581-1588. https:// doi.org/10.1039/c0sm00862a

41. Perevyazko IY, Delaney JT, Vollrath A, Pavlov GM, Schubert S, Schubert US (2011) Examination and optimization of the selfassembly of biocompatible, polymeric nanoparticles by highthroughput nanoprecipitation. Soft Matter 7:5030-5035. https:// doi.org/10.1039/c1sm05079f

42. Nair DP, Podgórski M, Chatani S, Gong T, Xi W, Fenoli CR, Bowman CN (2014) The thiol-Michael addition click reaction: a powerful and widely used tool in materials chemistry. Chem Mater 26:724-744. https://doi.org/10.1021/cm402180t

43. Späte A-K, Bußkamp H, Niederwieser A, Schart VF, Marx A, Wittmann V (2014) Rapid labeling of metabolically engineered cellsurface glycoconjugates with a carbamate-linked cyclopropene reporter. Bioconjug Chem 25:147-154. https://doi.org/10.1021/bc4004487

44. Oliveira BL, Guo Z, Bernardes GJL (2017) Inverse electron demand Diels-Alder reactions in chemical biology. Chem Soc Rev 46:4895-4950. https://doi.org/10.1039/c7cs00184c

45. Wu H, Devaraj NK (2016) Inverse electron-demand Diels-Alder bioorthogonal reactions. Top Curr Chem 374:3. https://doi.org/10. 1007/s41061-015-0005-z

46. Knall A-C, Slugovc C (2013) Inverse electron demand Diels-Alder (iEDDA)-initiated conjugation: a (high) potential click chemistry scheme. Chem Soc Rev 42:5131-5142. https://doi.org/10.1039/c3cs60049a

47. Liu DS, Tangpeerachaikul A, Selvaraj R, Taylor MT, Fox JM, Ting AY (2012) Diels-Alder cycloaddition for fluorophore targeting to specific proteins inside living cells. J Am Chem Soc 134:792-795. https://doi.org/10.1021/ja209325n

48. Schoch J, Staudt M, Samanta A, Wiessler M, Jäschke A (2012) Site-specific one-pot dual labeling of DNA by orthogonal cycloaddition chemistry. Bioconjug Chem 23:1382-1386. https://doi.org/ 10.1021/bc300181n

49. Yang J, Šečkute J, Cole CM, Devaraj NK (2012) Live-cell imaging of cyclopropene tags with fluorogenic tetrazine cycloadditions. Angew Chem Int Ed 51:7476-7479. https://doi.org/10.1002/anie.201202122

50. Frey H, Haag R (2002) Dendritic polyglycerol: A new versatile biocompatible material. Rev Mol Biotechnol 90:257-267. https:// doi.org/10.1016/S1389-0352(01)00063-0

51. Kurniasih IN, Keilitz J, Haag R (2015) Dendritic nanocarriers based on hyperbranched polymers. Chem Soc Rev 44:4145-4164. https:// doi.org/10.1039/C4CS00333K

52. Steinhilber D, Seiffert S, Heyman JA, Paulus F, Weitz DA, Haag R (2011) Hyperbranched polyglycerols on the nanometer and micrometer scale. Biomaterials 32:1311-1316. https://doi.org/10. 1016/j.biomaterials.2010.10.010

53. Khandare J, Mohr A, Calderón M, Welker P, Licha K, Haag R (2010) Structure-biocompatibility relationship of dendritic polyglycerol derivatives. Biomaterials 31:4268-4277. https://doi. org/10.1016/j.biomaterials.2010.02.001

54. Dommerholt J, Schmidt S, Temming R, Hendriks LJA, Rutjes FPJT, van Hest JCM, Lefeber DJ, Friedl P, van Delft FL (2010) Readily accessible bicyclononynes for bioorthogonal labeling and three-dimensional imaging of living cells. Angew Chem Int Ed 49: 9422-9425. https://doi.org/10.1002/anie.201003761

55. Sisson AL, Haag R (2010) Polyglycerol nanogels: highly functional scaffolds for biomedical applications. Soft Matter 6:4968-4975. https://doi.org/10.1039/c0sm00149j

Publisher's note Springer Nature remains neutral with regard to jurisdictional claims in published maps and institutional affiliations.

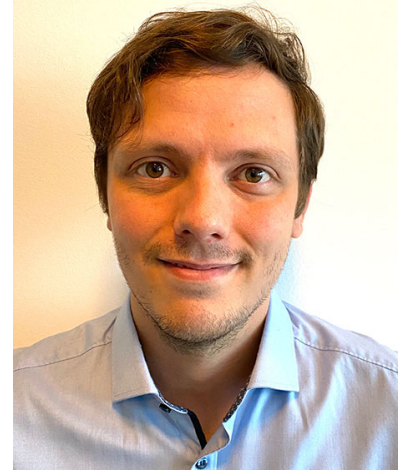

Alexander Oehrl obtained his BSc and MSc degrees at Freie Universität Berlin. In 2015 he visited the University of British Columbia in Vancouver (Canada) in a collaboration between the group of Prof. Haag and Prof. Kizhakkedathu to perform research on antithrombotic surfaces. He continued to do research on hyperbranched polyglycerols in the context of his doctoral studies in the group of Prof. Haag. The focus of his work is the establishment of synthetic parameters for nanogels from hyperbranched polyglycerols using inverse electron demand Diels-Alder reactions for the network formation. In addition, he works on the encapsulation behavior of nanogels for therapeutic proteins.

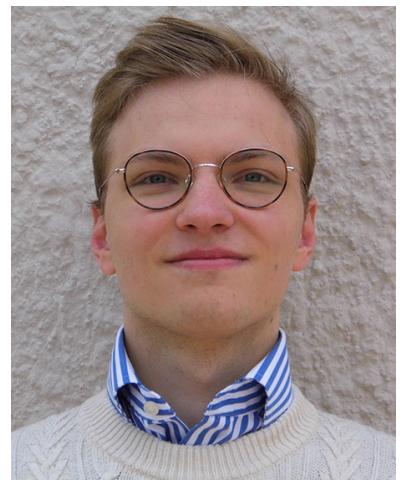

Sebastian Schötz started in the group of Prof. Dr. Rainer Haag at the Freie Universität Berlin as an internship student in the field of nanogels in November 2018. He then continued his research under the lead of Alexander Oehrl as a student research assistant. Currently he is doing his master thesis in the group of Prof. Dr. Rainer Haag to further investigate the inverse electron demand Diels-Alder-based nanogels.

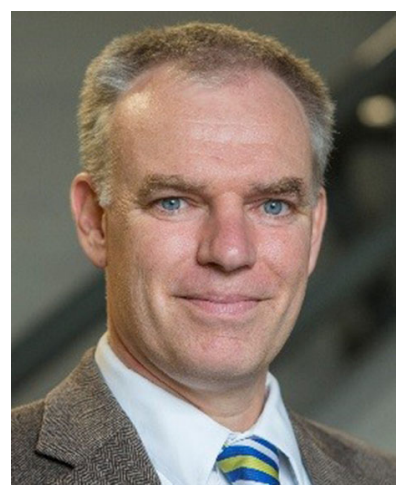

Rainer Haag is a Full Professor in Macromolecular Chemistry at the Freie Universität Berlin. His research interests are dendritic polymers as highly functional polymeric supports, macromolecular nanotransporters for DNA- and drug-delivery and protein resistant material surfaces. His scientific output is documented by $>$ 500 peer review publications and $>35$ patent applications. In 2019 he became an elected member of the German Academy of Technical Sciences (Acatech). For more information see the research group homepage: www.polytree. de.

Dear Matthias, I really enjoy our close collaboration with orthogonal expertise and hope that we can go on like this for many years to come! Rainer 